\title{
FACTORS THAT INFLUENCE THE BEHAVIOR OF YOUNG PEOPLE IN MAKING THE DECISION TO START A BUSINESS. CASE STUDY
}

\author{
Liana-Eugenia MESTER ${ }^{a}$, Andreea-Florina FORA ${ }^{b}$, \\ Nicoleta Georgeta BUGNAR ${ }^{c}$, Margit CSIPKÉS ${ }^{d}$ \\ a,b,c University of Oradea, Romania \\ ${ }^{d}$ University of Debrecen, Hungary
}

\begin{abstract}
This study aims to analyze the behavior when making the decision to become entrepreneurs of young people aged 21-23 (economics undergraduates in their final year at universities in Romania and Hungary). The tool used in the analysis is the questionnaire applied that revealed the factors making up the behavior when deciding to start a business. Knowing their motivation will allow them to understand action decisions, development plans, as well as the perception of today's world and the new reality. Similar studies have highlighted the link between the behavior of the young generation, including starting a business, and access to the Internet using new technologies (43\% of young people aged 21 to 24 spend between 4 and 8 hours a day in front of screens), lack of financial resources, difficulty in accessing funding sources, lack of career counseling or moral support from those close to you. Compared to the needs of students in Hungary, the study underlines, in the case of Romanian economists, the link between their behavior when facing the entrepreneurial decision and funding sources (lack of own funds, difficulty accessing funding sources), but also lack of career counseling. The identified solution is to support the establishment of a counseling center for economics students within the faculty following the model of the center that operates in the University of Hungary.
\end{abstract}

KEYWORDS: entrepreneurship, entrepreneurial behavior, career counseling, development plan.

\section{DOI: 10.24818/IMC/2021/01.13}

\section{INTRODUCTION}

The aim of the study proposed in this paper is to identify the factors underlying the behavior when deciding to start a business and the analysis of the manifestation in making the decision to become entrepreneurs of young people aged 21-24 (economics students in the final year at universities from Romania and Hungary).

The reason why the 2 countries were chosen for comparison is related to the existing functional links at university level (exchange of experience, joint activities with the participation of students from both countries), geographical proximity and social, economic, and cultural influences. The subjects of this study are economics students in the final year (bachelor's degree) / age category 21-24 years.

The premises at the basis of the study are related to the need to integrate into the labor market after completing their studies and putting into practice the skills acquired during training in undergraduate studies.

Studies conducted for this purpose highlight the factors that influence and / or motivate the behavior of the young generation in making the decision to start a business.

\footnotetext{
* Corresponding author. E-mail address: lmester@uoradea.ro
} 
Thus, in Romania, the behavior of the young generation in making the decision to start a business is influenced by: internet access with the use of new technologies (43\% of young people aged 21 to 24 spend between 4 and 8 hours a day in front of screens), lack of financial resources, difficulty in accessing sources of funding, lack of career counseling or moral support from those close to them, etc. In Hungary, according to studies, the behavior of the young generation in making the decision to start a business is motivated by: the need to achieve / desire to win, the place of control and the need for freedom / predilection in taking risks and self-sufficiency, self-confidence and optimism / initiative and responsibility, creativity / opportunity orientation / innovation, etc.

\section{LITERATURE REVIEW}

Entrepreneurship support in higher education has manifested itself in different ways (European Commission, 2008).

Unlike psychological studies highlighting the links between individual / personal factors (motivations, skills, tendency to take risks or predisposition to innovation) and elements of social context: family and expectations, social and institutional support for entrepreneurship (Baum, Frese, Baron, 2007) and sociological studies oriented towards understanding the socio-familial foundations of entrepreneurship, as well as the effects that entrepreneurial choices have on the family, status-role structure and social life in general (Blanchflower, 2000; Steele, 2004), economic studies include the description of key economic factors (lack of opportunities, costs and income, technology involved, etc.), as well as the study of economic developments and their effects on labor, as well as demographic factors of entrepreneurs (Audretsch \& Thurik, 2001; Cuervo, 2005 etc.).

In the European context, the Green Paper study was identified. Entrepreneurship in Europe (2003) a European Commission policy paper to encourage and support business start-ups and support.

Statistical data and information that characterize the decision-making behavior of starting a business are provided in a significant proportion by studies carried out in projects about at entrepreneurship.

\subsection{In Romania}

Following the existing studies, it is found that in Romania, even if there is a classification and a statistical hierarchy of motivations, this classification is not conclusive due to the fact that not only one factor, but several factors are taken into account when it comes to influencing the decision to start a company or start a business (Global Entrepreneurship Monitor, Global Report, 2014): desire for success, desire to be independent, desire for personal and professional affirmation, dissatisfaction with previous results, desire to have wealth, lack of occupation or job.

According to the study Barometer of education and entrepreneurial culture among students (Romania, 2014) Romanian students (final year, specialties with economic profile) would prefer in to be entrepreneurs and not employed at the end of their studies (57\%), and most would rather start their own business in the next 2 years (52\%). Among the reasons that determine them to start their own business, the surveyed students mention: self-fulfillment, the possibility to put into practice their own ideas, independence and the prospect of additional income. Among the obstacles that stand in the way of the decision to start their own business the following were mentioned: lack of start-up capital, fear of failure and uncertain economic situation. Even if the study was aimed at young people with entrepreneurial skills acquired during their studies, with no practical experience in the field of entrepreneurship, most of them argue that starting their own business should take place after gaining work experience; however, there are some who, more courageously or perhaps less consciously, claim that starting a business can take place immediately after graduation or even during college.

The Romanian Entrepreneurship Barometer (2016) identified five pillars to support entrepreneurship: taxation and regulation, access to finance, coordinated aid, entrepreneurial culture, and education. These pillars are considered the main factors causing other factors taken into 
account in the decision to start a business: tax facilities, easiness in starting a business, legislation and public policies that support entrepreneurship, types of financing (start- up, expansion, growth capital), support modalities (mentors, associations and clubs of entrepreneurs, business incubators, parks and business centers), tolerance to risk and failure, preference to act on their own, culture of innovation and research, appreciation of the well-being created through one's own business, training by participating in specific entrepreneurial courses or lifelong learning. These concerns belong to a mature segment of Romanian entrepreneurs: with accumulated life experience and entrepreneurial experience gained in the years of business development. Even if entrepreneurs in this business segment consider that business failure is perceived positively (learning opportunity), the fear of failure is one of the most important obstacles to the development of private initiative (indicates lack of necessary skills or a barrier to future initiatives). "The fear of failure remains one of the significant barriers to approaching entrepreneurship in Romania, given that eliminating the stigma of failure is critical for the development of personal initiative. When business failure has a very high cost imposed by society, potential entrepreneurs hardly choose this path" (Ernst \& Young Romania). Unlike mature entrepreneurs, startup entrepreneurs consider bureaucracy and access to finance to be the biggest obstacles; precarious education is the second major obstacle in developing a business in Romania.

The startups Barometer study (EY Impact Hub, 2018) highlights the limits felt in front of the decision to start your own business: attracting funding sources, precarious education - mentoring and discussions with other entrepreneurs are their main source of learning - the entrepreneurial education, unlike the academic one, develops based on contact with successful entrepreneurial stories.

Compared to the previous edition, the startups Barometer study (2019) shows an improvement in the perception of education and access to finance, which does not mean that these issues have been resolved or improved at the national level (especially as much as Romania ranks last among EU countries in the latest PISA assessment on the share of graduates).

The White Paper on SMEs (2021) makes a profile of the Romanian entrepreneur: "the Romanian entrepreneur in 2021 is a man, aged between 45 and 60, having economic training at university or postgraduate studies, his average entrepreneurial experience exceeds 20 years, he doesn't work in partnership and is the sole owner of the business" and groups the factors that influence the initiation / development of the business:

a) factors with a negative influence on starting / developing business: coronavirus pandemic, excessive bureaucracy, low environmental predictability for SMEs, state policies to support companies and the population in the current context, insufficient state capacity to manage economic problems, uncertainties of future developments, excessive taxation;

b) factors with a positive influence on starting / developing business: 6 out of 10 entrepreneurs intend to access structural funds (2020 only 3 out of 10), 4 out of 10 are self-financing ( 6 out of 10 in 2020), digital technologies: 7 out of 10 entrepreneurs use computers, the internet; 6 out of 10 use business operating software; 5 out of 10 use the electronic signature.

\subsection{In Hungary}

The entrepreneurship education is encouraged by Strategy on Lifelong Learning in Hungary (2005). Interest in entrepreneurship among students and graduates a grew rapidly. Bridge Budapest (2016) has inventory entrepreneurial intentions of students: six out of ten young people in the 20-35 age group have concrete plans for their own business and almost $60 \%$ said they know a company which was founded by a young Hungarian and gained global visibility. The reasons why there are delays in starting a business have changed over time. Because financial security and risk avoidance fell to $18 \%$, from $36 \%$ in 2015 , entrepreneurship education remained a major barrier to starting a business. Global Entrepreneurship Monitor (GEM) emphasizes a growing interest in entrepreneurship. According to the data, $16 \%$ of students surveyed plan to start a business in the next three years. The 
main barriers to establishment are "the unbearable education system and the negative media attention" (GEM Hungary, 2016). The study concluded that, in the long run, the challenge will be to make the education system more supportive of entrepreneurship.

Young people have the opportunity to choose between initiatives and online platforms for students: Junior Achievement, Job Shadowing, Student Entrepreneurs or Visit the Company which promotes good practices and encourages entrepreneurial initiatives. The national platform, the Association of Young Entrepreneurs (FIVOSZ), also offers programs and support for young entrepreneurs, including the possibility of connecting young entrepreneurs with experienced entrepreneurs. Supporting students and graduates in starting a business is a topical issue even if the emphasis has been more on skills development and less on support for start-ups (Supporting Entrepreneurship and Innovation in Higher Education in Hungary, 2017).

The study Entrepreneurship intentions and activity of students in Hungary (2017) conducted at the University of Miskolci highlights the fact that students in Hungary prefer to work as employees after graduation $(86.1 \%)$ and have low entrepreneurial intentions; entrepreneurial intentions increase among students $(36.4 \%)$ after 5 years after graduation: economics students are the most open to entrepreneurship, and social science students were the least reluctant.

Determining factors in the entrepreneurial decision are:

a) family support: family business influences students' entrepreneurial intentions and risk-taking and additional responsibilities related to setting up a company;

b) competences formed during university studies and university counseling (entrepreneurial counseling centers);

c) new communication methods and new knowledge transfer practices.

\section{RESEARCH METHODOLOGY}

The research methodology used in this paper consists in applying an online questionnaire to young people aged 21-23 (economics students in the final year at universities in Romania and Hungary). The questionnaire applied was made using the Google Forms application and is available at the following link: https://docs.google.com/forms/d/e/1FAIpQLSdNQvcCUhwxZ3racF5ywwgr0FZ8 MTBYYdfXfypaKkkq9DorFg/viewform?usp=sf_link.

The questionnaire on identifying the factors underlying the behavior in front of the decision to start a business was answered by 450 students (198 students from the University of Debrecen and 252 students from the University of Oradea). This questionnaire was applied from January to June 2021. The questionnaire was structured in ten parts (the name of the student is anonymous in the study).

The first part was to express readiness to start a business.

The second part focused on the field of activity in which the business would be initiated, and the following elements considered were access to information, respectively assuming responsibility. In the fifth part of the questionnaire, students were asked what the challenges of the current period are. In the current context, students were asked about the motivation that would underlie their behavior in business. In the seventh part of the questionnaire, students were asked about their abilities and, if they existed, what the level of confidence in their own abilities was.

The eighth part of the questionnaire asks students about the level of entrepreneurial skills and how entrepreneurial knowledge was acquired. The penultimate part of the questionnaire investigates the availability of further entrepreneurial training.

In the last part of the questionnaire, students are asked about the development of knowledge and skills in the field of sustainable development.

Unfortunately, throughout the application of the questionnaire we faced the reluctance of students to respond to this survey, as a result we were forced to limit ourselves to the 450 responses received (only from students of the 2 universities), although we recognize that initially we targeted a much larger sample. 


\section{RESULTS}

The answers recorded in the applied questionnaire were analyzed comparatively (Romania and Hungary) in order to reflect the availability of students in the final year to start a business and to identify the factors that were the basis for the decision to start a business.

Figure 1 shows that the share of students who have expressed a desire to start a business immediately after graduation is unfortunately relatively low. In Romania $21 \%$ of respondents said that there is availability to start a business, while in Hungary the percentage is slightly higher than $27 \%$. We consider that a factor that influenced the percentages recorded in this question is the period of uncertainty experienced at the time of applying the questionnaire, we are talking here about the impact of the COVID-19 pandemic.

Q1: Romania

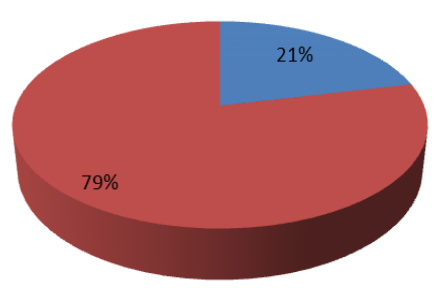

$\because$ Yes $\square$ No
Q1: Hungary

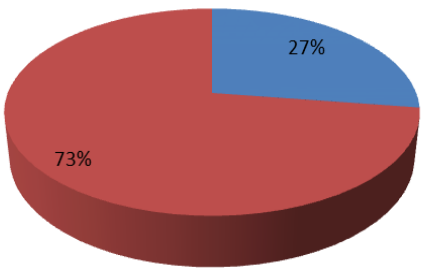

$\because$ Yes $\square$ No

Figure 1. Q1: Is there availability in starting a business?

Source: made by the authors based on the answers received in The questionnaire on identifying the factors that influence the behavior when making the decision to start a business

According to Figure 2 the question Can raising awareness and awareness of the benefits of entrepreneurship be an option for starting and developing a business? was answered affirmatively by $99 \%$ of students in Romania and by $90 \%$ of students in Hungary. This response indicates the importance of entrepreneurship courses conducted during undergraduate studies, as well as extracurricular entrepreneurship seminars that facilitate the connection of students with entrepreneurs by providing examples of good practice. We believe that these activities are very important and should exist in all universities, and that students should be facilitated access to such information.

\section{Q2: Romania}

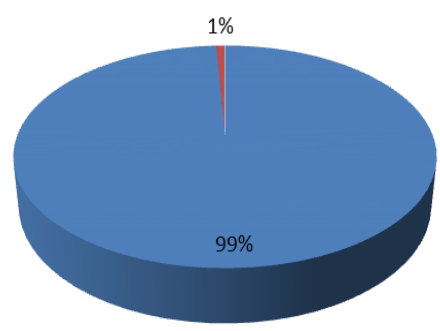

$\because$ Yes $n$ No
Q2: Hungary

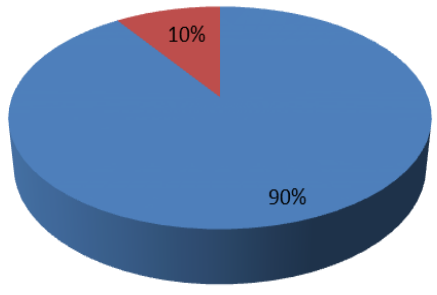

$\because$ Yes $\square$ No

Figure 2. Q2: Could getting informed and raising awareness of the benefits of entrepreneurship be an option for starting and developing a business?

Source: made by the authors based on the answers received in The questionnaire on identifying the factors that influence the behavior when making the decision to start a business 
Figure 3 provides the answers given by students at the third question: Are you a person who takes responsibility on your own initiative and acts accordingly, without anyone asking you to do so? $97 \%$ of students from University of Oradea answered affirmatively, while the percentage is slightly lower, $83 \%$ in the case of students from the University of Debrecen.

\section{Q3: Romania}

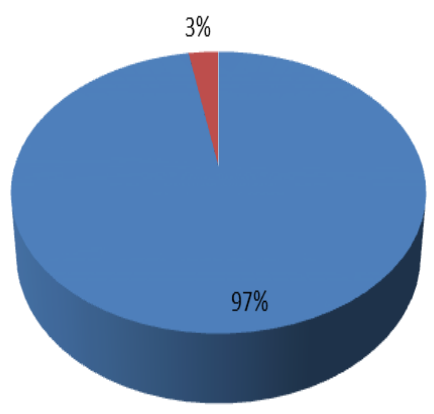

- Yes $\square$ No
Q3: Hungary

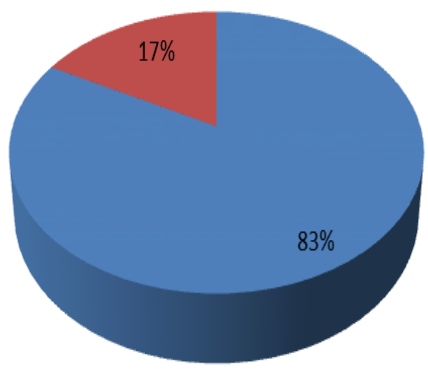

-Yes №

Figure 3. Q3: Are you a person who assumes responsibilities voluntarily and acts accordingly without anyone asking you to do so?

Source: made by the authors based on the answers received in The questionnaire on identifying the factors that influence the behavior when making the decision to start a business

By means of including question number 4 we wanted to identify the challenges of young people in the current period. In Romania, it seems that the main challenges that young people face are: lack of face-to-face socialization (32\%) and lack of motivation (19\%), followed closely by fluctuating emotional states (17\%). \%). In Hungary, the main challenge for young people is lack of motivation ( $45 \%$ ), followed by fatigue ( $22 \%$ of respondents). Given the answers provided by students in Romania we are entitled to believe that the main factor that influenced the answers is the COVID19 pandemic, in view of the fact that both courses and seminars were held in online format, which prevented the real face-to-face interaction.

\section{Q4: Romania}

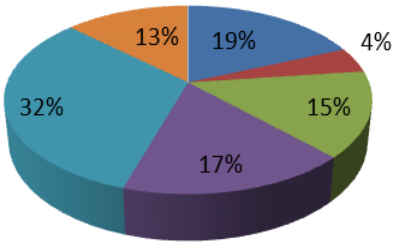

$$
\begin{aligned}
& \text { - lack of motivation } \\
& \text { - fatigue }
\end{aligned}
$$

n lack of face-to-face socialization $\mathbf{n}$ others

\section{Q4: Hungary}

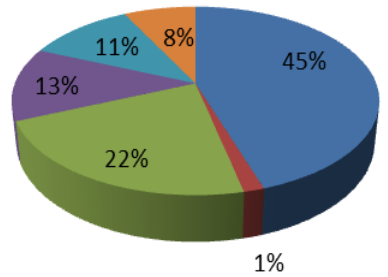

- lack of motivation

- boredom

n fatigue

- fluctuating emotional states

- lack of face-to-face socialization $\mathbf{m}$ others

Figure 4. Q4: What do you consider to be the challenges of young people today?

Source: made by the authors based on the answers received in The questionnaire on identifying the factors that influence the behavior when making the decision to start a business 
Question number 5 was intended to identify the factors that affect the decision to start a business. As Figure 5 indicates, both students in Romania and those in Hungary consider that the main factor affecting the decision to start a business is the lack of own financial sources (52\% in Romania and $55 \%$ in Hungary). In addition, $29 \%$ of Romanian students consider that another important factor is the difficulty of accessing external funding sources. Regarding this aspect, a possible solution would be to participate in workshops specialized in attracting European funds, workshops that could be made available by universities to students as extracurricular activities.

\section{Q5: Romania}

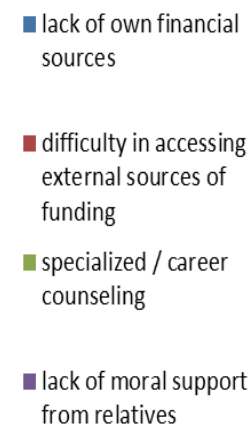

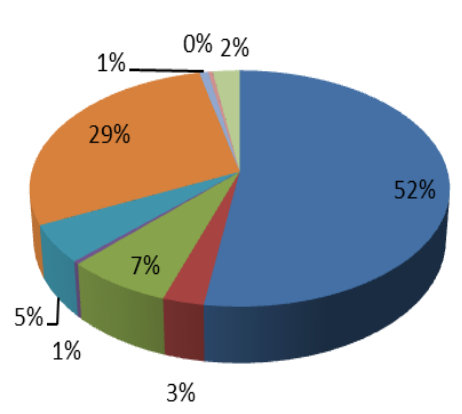

Q5: Hungary

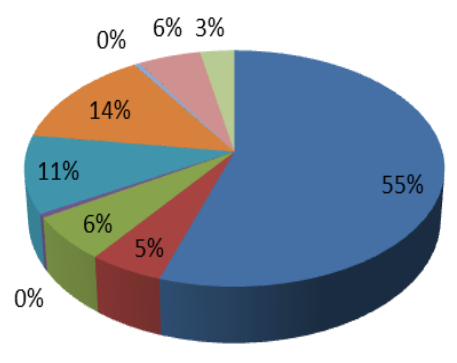

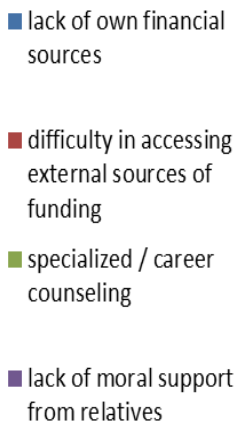
from relatives

\section{Figure 5. Q5: What do you consider to be the factors that affect the decision to start a business?}

Source: made by the authors based on the answers received in The questionnaire on identifying the factors that influence the behavior when making the decision to start a business

Figure 6 highlights the abilities of students who support their own initiative. In Romania, 36\% of students consider that the most important thing is the good management of emotions, and in Hungary, $44 \%$ of students believe that financial education is the main skill that supports their initiative. This shows us once again the importance of the entrepreneurial counseling centers present in Hungarian universities.

Q6: Romania

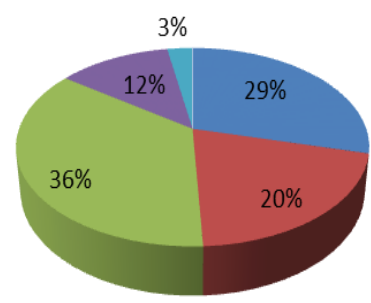

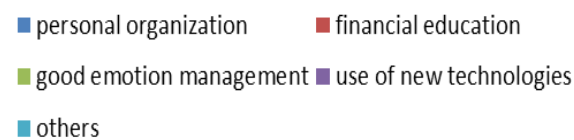

Q6: Hungary

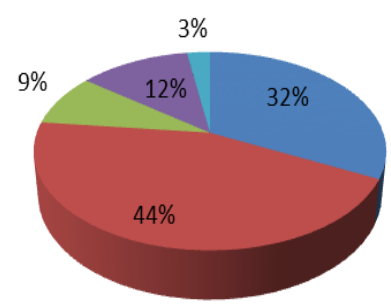

- personal organization $\quad$ financial education

good emotion management $\mathbf{m}$ use of new technologies

others

Figure 6. Q6: What are the skills that support your initiative?

Source: made by the authors based on the answers received in The questionnaire on identifying the factors that influence the behavior when making the decision to start a business 
In our study we intended to find out if students are willing to increase their knowledge by participating in various training courses. According to Figure 7, we can see that only $78 \%$ of Romanian students have this willingness, whereas $97 \%$ of Hungarian students have expressed their intention to participate in complementary courses. These percentages indicate that a campaign should be carried out in Romanian universities to inform students on the importance of completing their studies with various training courses.

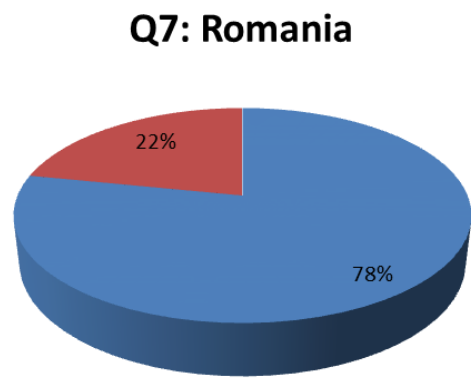

$\because$ Yes $=$ No
Q7: Hungary

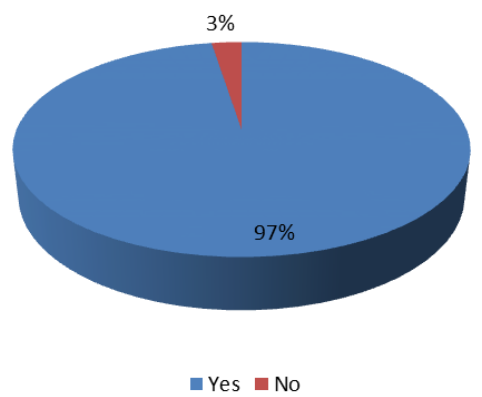

Figure 7. Q7: Do you have the availability to improve certain knowledge by participating in different training courses?

Source: made by the authors based on the answers received in The questionnaire on identifying the factors that influence the behavior when making the decision to start a business

In section eight of the questionnaire, we wanted to identify where the students' entrepreneurial knowledge was acquired. In Romania, $48 \%$ of students answered that they acquired entrepreneurial knowledge by participating in complementary / advanced courses (eg entrepreneurial skills, innovative entrepreneurship). In Hungary, $26 \%$ of students consider that they have acquired entrepreneurial knowledge equally through access to information and specialized sources and through participation in complementary / advanced courses. We believe that the large number of respondents in Romania who consider that they have acquired entrepreneurial knowledge by participating in complementary / advanced courses is due to the fact that at the University of Oradea, during the application of the questionnaire, entrepreneurship there were student-oriented projects carried out.

Q8: Romania

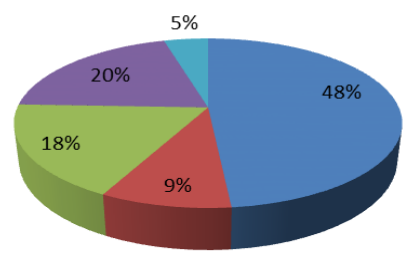

- following participation in complementary / advanced courses

- participation in business plan competitions

maccess to information and specialized sources

- participation in the practice sessions and / or internship

n counseling within specialized structures
Q8: Hungary

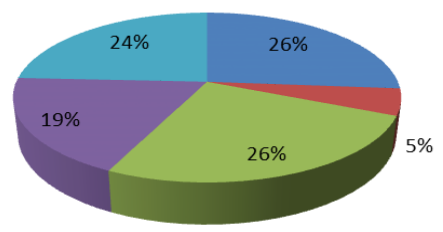

- following participation in complementary / advanced courses

= participation in business plan competitions

waccess to information and specialized sources

m participation in the practice sessions and / or internship

- counseling within specialized structures

Figure 8. Q8: Entrepreneurial knowledge has been acquired

Source: made by the authors based on the answers received in The questionnaire on identifying the factors that influence the behavior when making the decision to start a business 
In Figure 9 we can analyze how students responded to the question: Do you consider it necessary to develop knowledge and skills in the field of sustainable development, by ensuring a balance between environmental issues, social cohesion, and economic growth? It is observed that in a very high percentage both Romanian and Hungarian students answered affirmatively (99\% in Romania and $96 \%$ in Hungary).

Q9: Romania

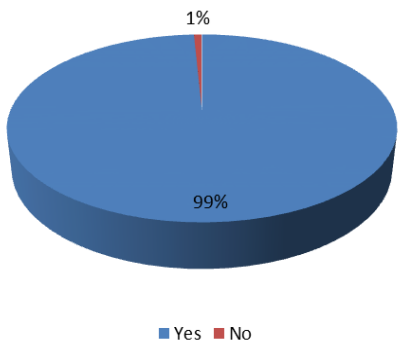

Q9: Hungary

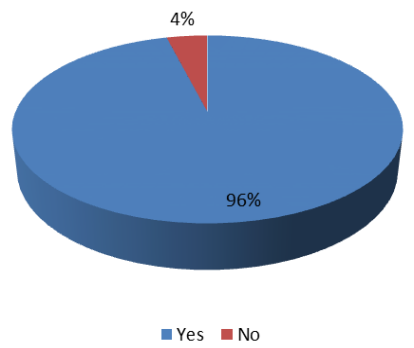

Figure 9. Q9: Do you consider it necessary to develop knowledge and skills in the field of sustainable development, by ensuring a balance between environmental issues, social cohesion, and economic growth?

Source: made by the authors based on the answers received in The questionnaire on identifying the factors that influence the behavior when making the decision to start a business

The last part of the study looked at whether students are confident in their own abilities. According to Figure 10, it is observed that the percentages of answers are similar Romanian and Hungarian students. $81 \%$ of Romanian students and $83 \%$ of Hungarian students stated that they have confidence in their own abilities.

Q 10: Romania

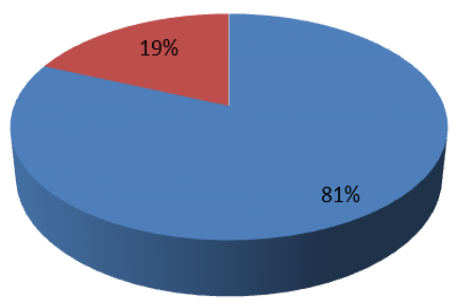

$\square$ Yes $\square$ No
Q 10: Hungary

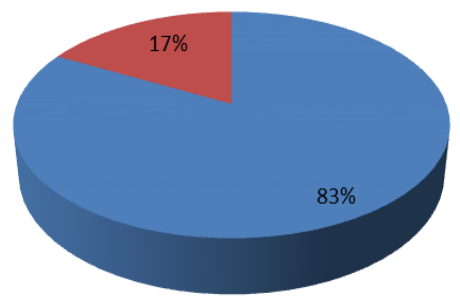

$\because$ Yes $\square$ No

Figure 10. Q10: Do you trust your abilities?

Source: made by the authors based on the answers received in The questionnaire on identifying the factors that influence the behavior when making the decision to start a business

In the future, we intend to extend this study to several universities in Romania and Hungary to see if the results obtained in this study can be generalized for these two countries.

\section{CONCLUSIONS}

Entrepreneurial skills have a significant impact on the decision to start a business in the context of factors such as: the existence of a flexible economic and social environment, conducive to business development (legislation, free competition), the existence of a proactive culture of entrepreneurship, 
in the sense of a high degree of credibility of people who set up / run their own business, the existence of entrepreneurship education in schools and universities and a system of continuous training of individuals to assimilate knowledge and skills specific to entrepreneurship (Dragan, M., 2016).

Given that the labor market has undergone a number of major changes and will require skills adapted to change, entrepreneurship is the solution to make the labor market more flexible.

Even if the entrepreneurial intentions of final year (undergraduate) students - Romanian and Hungarian - are still low, they can still be encouraged and supported by: updating the regulatory framework for entrepreneurship (in Hungary), adapting programs to current changes and the characteristics of the new generation of students (emphasis on practical knowledge) - in Romania and Hungary), the inclusion in the curricula of some entrepreneurship disciplines (in Romania), the establishment of entrepreneurial counseling centers in Romanian universities following the model of those existing in Hungarian universities.

\section{REFERENCES}

Audretsch, D.B. \&Thurik, R. (2001). What's new about the new economy? Sources of growth in the managed and entrepreneurial economies, Industrial and Corporate Change, 10(1), 267-315.

Barometrul educației și culturii antreprenoriale în rândul studenților (2014). https://files.finantare.ro /2014/studiu-EY-barometrul-educatiei-si-culturii-antreprenoriale.pdf .

Barometrul antreprenoriatului românesc (2016). https://cdn.cursdeguvernare.ro/wp-content/uploads/ 2016/05/EY_Barometrul-antreprenoriatului-romanesc_2016_sinteza.pdf.

Barometrul startup-urilor (2018). https://www.impacthub.ro/wp-content/uploads/2019/01/EY_ Barometrul-startup-urilor-din-Romania-2016.pdf .

Barometrul startup-urilor (2019). https://startarium.ro/articol/barometrul-startupurilor-2019 .

Baum, J.R., Frese, M. \& Baron, R. (ed.). (2007). The Psychology of Entrepreneurship. Lawrence Erlbaum Associates, Mahawah, NJ.

Blanchflower, D.G. (2000). Self-employment in OECD countries, Labour Economics, 7(5), 471-505.

Carta Albă a IMM-urilor (2021). http://cnipmmr.ro/2021/09/29/lansarea-lucrarii-carta-alba-a-immurilor-din-romania-editia-a-19-a/.

Cuervo, A. (2005). Individual and environmental determinants of entrepreneurship, International Entrepreneurship and Management Journal, 1(3), 293-311.

Drăgan, M. (2016). Studiu privind importanța competențelor antreprenoriale pe piața muncii, https://econ.ubbcluj.ro/.

Gubik, A.S. \& Farkas, S. (2017). Entrepreneurship intentions and activity of students in Hungary, University of Miskolci, https://www.guesssurvey.org/resources/nat_2016/GUESSS_Report_ 2016_Hungary.pdf .

Global Entrepreneurship Monitor, Raport global (2014). https://www.gemconsortium.org/report.

Global Entrepreneurship Monitor, Raport global (2016). https://www.gemconsortium.org/report.

Green Paper. Entrepreneurship in Europe, COM (2003) 27 final, European Commission, Brussels 21.1.2003.

Gubik, A.S. (2013). A magyar hallgatók vállalkozásinditó szándékát befolyásoló tényezök modellje: Ajzen tervezett magatartás elméletének kiterjesztése. (The model of factors affecting business start-ups of Hungarian students: the expansion of Ajzen's Theory of Planned Behaviour), Vezetéstudomány (Budapest Management Review), 44(7-8), 18-29.

Gubik, A.S., Bartha, Z. (2017): Cultural Characteristics and the Entrepreneurial Intentions of University Students, Theory Methodology Practice: Club of Economics in Miskolc, 13(02) 3-12. doi:10.18096/TMP.2017.02.01. 
Gubik, S.A. Farkas, Sz. (2017): Hallgatói vállalkozások Magyarországon, Taylor: Gazdálkodás-és szervezéstudományi folyóirat: A Virtuális Intézet Közép-Európa Kutatására Közleményei 9:(2) 168-178, https://www.researchgate.net/profile/A_S_Gubik/publication/321613658_Hallgatoi_ vallalkozasok_Magyarorszagon/links/5a2903e90f7e9b71dd100afb/Hallgatoi-vallalkozasokMagyarorszagon.pdf .

Gubik, A.S. \& Farkas, S. (2016). Student Entrepreneurship in Hungary: Selected Results Based on GUESSS Survey, Entrepreneurial Business and Economics Review, 4(4), 123-139, DOI: http://dx.doi.org/10.15678/EBER.2016.040408.

Passaro, R., Quinto, I. \& Thomas, A. (2018). The impact of higher education on entrepreneurial intention and human capital, Journal of Intellectual Capital, 19(1), 135-156. https://doi.org/ 10.1108/JIC-04-2017-0056.

Steele, G.R. (2004). Understanding economic man. Psychology, rationality, and values, The American Journal of Economics and Sociology, 63(5), 1021-1055.

https://www.schooleducationgateway.eu/downloads/entrepreneurship/Hungary_151022.pdf

Supporting Entrepreneurship and Innovation in Higher Education in Hungary (2017). OCDE Skills Studies, https://www.oecd-ilibrary.org/industry-and-services/supporting-entrepreneurship-andinnovation-in-higher-education-in-hungary/overview-of-the-hungarian-higher-educationsystem_97892642733 44-6-en. 